Огляди літератури, оригінальні дослідження, погляд на проблему, ювілеї

УДК 615.225+616-08+616.12-008.331.1+616.61-002.3

DOI 10.11603/1811-2471.2019.v0.i1.10056

\title{
ЕФЕКТИВНІСТЬ КАНЕФРОНУ Н У КОМПЛЕКСНОМУ ЛІКУВАННІ СУБКЛІНІЧНИХ ОЗНАК УРАЖЕННЯ СУДИН У ХВОРИХ НА АРТЕРІАЛЬНУ ГІПЕРТЕНЗІЮ ІЗ ХРОНІЧНИМ ПІЄЛОНЕФРИТОМ
}

\section{Івано-Франківський національний медичний університет}

\author{
๑О. Р. Лучко
}

РЕЗЮМЕ. Проаналізовано результати лікування 40 хворих на артеріальну гіпертензію (АГ) ІІ ступеня із хронічним пієлонефритом (ХПН), яких було поділено на дві групи: 20 пацієнтів І групи отримували базову терапію; 20 хворих II групи на тлі базової терапії отримували препарат «Канефрон Н».

Мета - вивчення ефективності препарату «Канефрон Н» у комплексному лікуванні субклінічних ознак ураження судин у хворих на артеріальну гіпертензію із хронічним пієлонефритом.

Матеріал і методи. Проаналізовано результати лікування 40 хворих на АГ ІІ ступеня з ХПН, яких, залежно від лікування, поділено на дві групи. I групу склали 20 хворих, які отримували базову терапію: фіксовану низькодозову комбінацію периндоприлу аргінін - 2 мг, індапаміду - 0,625 мг, амплодипіну - 5 мг та аторвастатину - 10 мг; II 20 хворих, які отримували на тлі базової терапії канефрон Н по 2 драже 3 рази на добу всередину протягом місяця. Повторний курс запропонованої схеми лікування проводили через 6 місяців.

Оцінку ефективності запропонованого лікування визначали за динамікою показників пружно-еластичних властивостей судин (швидкість поширення пульсової хвилі - ШППХ, плечогомілковий судинний індекс - CAVI, індекс жорсткості аорти - ІЖА, товщина інтимо-медійного комплексу - ТІМК) та ендотеліальної дисфункції (ендотелін-1 - ЕТ-1, ендотелійзалежна вазодилатація - ЕЗВД і ендотелійнезалежна вазодилатація - ЕНВД).

Результати. У ході лікування відзначали зниження ШППХ $(p<0,001)$ і CAVI $(p<0,001)$ у хворих двох груп, однак більш виражені зміни наприкінці лікування були у хворих II групи. Упродовж року ІЖА (р<0,001) знижувався під впливом лікування у всіх хворих однаковою мірою, проте значуще зменшення ТІМК відзначали швидше у хворих II групи - через 6 місяців $(p<0,01)$ проти 12 місяців $(p<0,001)$ у хворих I групи.

Канефрон Н у комплексному лікуванні сприяв вираженішому зниженню вмісту ET-1 ( $<0,001)$, порівняно 3 базовою терапією, при цьому спостерігали суттєве поліпшення функції ендотелію за більш динамічним збільшенням ЕЗВД ( $<<0,001)$ та ЕНВД ( $<<0,001)$.

Висновки. 1. Канефрон Н у комплексі з комбінованою низькодозовою антигіпертензивною терапією сприяє регресу субклінічних ознак ураження судин у хворих із коморбідною патологією.

2. Тривале застосування препарату «Канефрон Н» у хворих на АГ із ХПН доцільне, безпечне і достатньо ефективне.

КлючОВІ СлОВА: артеріальна гіпертензія; хронічний пієлонефрит; субклінічні ознаки ураження судин; канефрон Н.

Вступ. Останніми роками значну увагу приділяють вивченню ураження судин у розвитку артеріальної гіпертензії (АГ), що виступають, з одного боку, як орган-мішень, а з іншого - орган, який реалізує багато ланок патогенезу [1]. За результатами останніх досліджень встановлено, що підвищення жорсткості судинної стінки, яке відбувається через зміну пружно-еластичних властивостей артерій та ендотеліальну дисфункцію (ЕД), є важливим інтегральним предиктором розвитку серцево-судинних та ниркових подій $[1,2]$. Незважаючи на достатню доказову базу про розвиток ригідності артеріальних судин у патогенезі АГ, питання своєчасної корекції ураження артерій на доклінічній стадії у хворих на АГ із хронічним пієлонефритом (ХПН) є суперечливими.

Застосування фітопрепаратів у комплексному лікуванні хворих на АГ із ХПН становить певний інтерес з огляду на їхні очевидні переваги над синтетичними засобами - відсутність ускладнень та небажаних побічних ефектів [3]. На сьогодні накопи- чено великий досвід використання рослинного препарату «Канефрон Н» («Біонорика СЕ», Німеччина), до складу якого входять стандартизовані за складом біологічно активних речовин компоненти лікарських рослин - трави золототисячника (Centaurium sp.), кореня любистку (Levisticum officinale) і листя розмарину (Rosmarinus officinalis L.) [3-5]. Препарат має протизапальну, антимікробну, спазмолітичну, діуретичну дії, покращує нирковий кровообіг i, за деякими даними, при регулярному застосуванні сповільнює темпи зниження швидкості клубочкової фільтрації [6].

Незважаючи на перелічені властивості, на сьогодні мало наукових досліджень щодо вивчення ефективності цього фітопрепарату в комплексному лікуванні хворих на коморбідну патологію, а наявний науковий досвід стосується лікування інфекцій сечовидільних шляхів [3], діабетичної і дисметаболічної нефропатії [4, 5] та артеріальної гіпертензії [4-6]. Застосовуючи суміш рослин, кожна з яких володіє специфічною дією, можна 
Огляди літератури, оригінальні дослідження, погляд на проблему, ювілеї

забезпечити комплексний різнобічний позитивний вплив на судини на субклінічному рівні.

Мета дослідження - вивчення ефективності препарату «Канефрон Н» у комплексному лікуванні субклінічних ознак ураження судин у хворих на АГ з ХПН.

Матеріал і методи дослідження. Проаналізовано результати лікування 40 хворих (24 чоловіки та 16 жінок у віці від 35 до 70 років, $58(45 ; 68)$ років на АГ ІІ ступеня з ХПН. Тривалість АГ становила $8(5 ; 15)$, а ХПН - $5(3 ; 7)$ років. У 21 (52,5 \%) хворого на АГ із ХПН встановлено хронічну хворобу нирок (ХХH) І стадії (швидкість клубочкової фільтрації (ШКФ) - 117,2 $(95,8 ; 119,5)$ мл/Хв × 1,73 м²), у 19 (47,5 \%) - ХХН ІІ стадії (ШКФ - 82,2 (75,4; $88,0)$ мл/Хв $\times 1,73 \mathrm{~m}^{2}$ ).

Основними критеріями включення хворих у дослідження були наявність АГ ІІ стадії ІІ ступеня та ХПН в неактивній фазі - не менш ніж через 6 місяців після останнього загострення, письмова згода хворого. Критеріями виключення з дослідження були вторинна артеріальна гіпертензія, супутня ішемічна хвороба серця, хронічна серцева недостатність III-IV функціонального класу (за класифікацією NYHA), хронічна ниркова недостатність, діабетична нефропатія та інші захворювання, які могли 6 вплинути на результати дослідження, непереносимість запропонованих медикаментозних засобів.

Для вивчення ефективності препарату «Канефрон Н» у комплексному лікуванні субклінічних ознак ураження судин хворих на АГ із ХПН рандомізували на дві групи. Усі хворі були репрезентативні за стадіями АГ, ХХН і ШКФ. І групу склали 20 хворих на АГ з ХПН, які отримували базову терапію; II - 20 хворих на АГ із ХПН, які отримували на тлі базової терапії нефропротектор природного походження «Канефрон Н» («Канефрон Н», Біонорика, Німеччина) по 2 драже 3 рази на добу всередину протягом місяця.

Базова терапія полягала у призначенні фіксованої низькодозової комбінації іАПФ периндоприлу аргінін - 2 мг, діуретика тіазидового ряду індапаміду - 0,625 мг, амплодипіну - 5 мг на добу та аторвастатину - 10 мг на добу.

Комплексну терапію із включенням канефрону Н хворі на АГ із ХПН отримували упродовж одного місяця. Повторний курс запропонованої схеми лікування проводили через 6 місяців.

Тривалість спостереження становила 12 місяців. Поглиблений клінічно-лабораторний моніторинг хворих проводили чотири рази: до лікування, через 1, 6 та 12 місяців лікування. Отримані результати порівнювали з показниками 20 практично здорових людей.

Оцінку ефективності фіксованої низькодозової комбінації антигіпертензивних препаратів та канефрону Н визначали за динамікою показників пружно-еластичних властивостей судин та ендотеліальної дисфункції.

Вимірювання швидкості поширення пульсової хвилі (ШППХ) проводили методом комп'ютерної реографії із синхронною реєстрацією реоплетизмограм плечової і гомілкової артерій: ШППХ=L(м)/ T(c); де L - віддаль у метрах (м) на магістралі «плече - гомілка", ділили на різницю між початком наповнення плечової і гомілкової артерій $(T, c)$.

Відтак вираховували плечогомілковий судинний індекс (CAVI, cardio-ankle vascular index) за такою формулою (К. Shiгаі та ін., 2011): CAVI=2p $\times$ In (Ps/Pd) $\times P W V 2 / \Delta P$, де PWV - швидкість поширення пульсової хвилі на судинному відрізку "плече-гомілка", Ps - систолічний артеріальний тиск крові, Pd - діастолічний артеріальний тиск

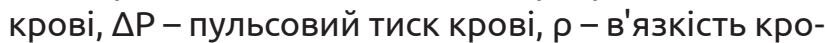
ві (величина стабільна - 1,03).

Значення індексу жорсткості аорти (ІЖА) встановлювали за величинами пульсового артеріального тиску та ударного об'єму (Г. Д. Радченко, Ю. М. Сіренко, 2009) за формулою: ІЖА=ПАТ (мм рт. ст.)/УО (мл), де ПАТ - пульсовий артеріальний тиск (мм Рт. ст.), УО - ударний об'єм (мл).

Товщину інтимо-медійного комплексу (ТIMK) визначали методом доплерографії по задній стінці загальної сонної артерії з обох сторін з використанням датчика 7,5 МГц на приладі «Logiq 500» (Кгаnzbuhler, Німеччина).

Для визначення ендотелійзалежної (ЕЗВД) та ендотелійнезалежної (ЕНВД) вазодилатації вимірювали діаметр плечової артерії натщесерце (у спокої), через 90 с після декомпресії артерії (ЕЗВД) та через 5 хв після приймання 0,5 мг нітрогліцерину (ЕНВД) за методом D. S. Celermajer (1992) у модифікації О. В. Іванової (1998). Вміст ендотеліну-1 (ЕT-1) у крові визначали імуноферментним методом (набір Enzo Life Sciences, Англія).

Статистичну обробку отриманих результатів проводили з використанням електронних таблиць Microsoft Excel 2016, стандартного пакета програми "Statistica 13.0 for Windows" ("STAT SOFT», США). Результати представлено у вигляді медіани (Ме) та меж інтерквартильного відрізка (25; 75 \%).

Результати й обговорення. У ході нашого дослідження з'ясовано, що у всіх хворих на АГ із ХПН спостерігали розвиток субклінічних ознак пошкодження судин, а це обґрунтовує доцільність розробки нових методичних підходів щодо корекції коморбідної патології.

Із представлених у таблиці 1 даних видно, що ШППХ і CAVI у хворих на АГ із ХПН під впливом комбінованого низькодозового антигіпертензивного лікування через 1 місяць вірогідно знизилися на 7,0\% $(p=0,0206)$ та 7,2\% $(p=0,0066)$, а при 
Огляди літератури, оригінальні дослідження, погляд на проблему, ювілеї

комплексному застосуванні канефрону Н - на 7,2 \% $(p=0,0241)$ та $8,9 \%(p=0,0472)$ відповідно, порівняно з вихідними їхніми рівнями (табл. 1). 3 часом (через 6 місяців лікування) показники ШППX і CAVI у пацієнтів двох груп продовжували поліпшуватися і наприкінці терміну дослідження досягли зниження ШППХ на $11,5 \%(p<0,001)$ та $19,9 \%(p<0,001)$, а CAVI - на $12,1 \%(p<0,001)$ та $20,8 \%(p<0,001)$ у хворих I і II груп відповідно. Слід зазначити, що наприкінці лікування значення ШППХ та CAVI були вірогідно нижчими, порівняно з першим місяцем терапії, у випадку додаткового використання канефрону Н: для ШППХ на 13,8 \% ( $=0,0011)$, а для CAVI- на $13,3 \%(p=0,0027)$.

Таблиця 1. Динаміка показників пружно-еластичних властивостей судин у хворих на артеріальну гіпертензію з хронічним пієлонефритом, Ме $(25,75 \%)$

\begin{tabular}{|c|c|c|c|c|c|}
\hline \multirow{2}{*}{$\begin{array}{l}\text { Показник, од. виміру, } \\
\text { значення у здорових }\end{array}$} & \multirow{2}{*}{$\begin{array}{l}\text { Групи } \\
\text { хворих }\end{array}$} & \multicolumn{4}{|c|}{ Період дослідження } \\
\hline & & до лікування & $\begin{array}{c}\text { через } 1 \text { міс. } \\
\text { лікування }\end{array}$ & $\begin{array}{c}\text { через } 6 \text { міс. } \\
\text { лікування }\end{array}$ & $\begin{array}{l}\text { через } 12 \text { міс. } \\
\text { лікування }\end{array}$ \\
\hline \multirow{2}{*}{$\begin{array}{c}\text { ШППХ, м/с; } \\
9,24 \\
(8,75 ; 10,03)\end{array}$} & I & $\begin{array}{c}13,99 \\
(12,80 ; 14,85)^{*}\end{array}$ & $\begin{array}{c}13,01 \\
(12,14 ; 13,76)^{\prime \prime}\end{array}$ & $\begin{array}{c}12,98 \\
(12,35 ; 13,71)^{\prime \prime}\end{array}$ & $\begin{array}{c}12,38 \\
(11,33 ; 13,19) "\end{array}$ \\
\hline & II & $\begin{array}{c}13,70 \\
(12,95 ; 14,60)^{*}\end{array}$ & $\begin{array}{c}12,72 \\
(11,52 ; 13,48) "\end{array}$ & $\begin{array}{c}12,43 \\
(11,84 ; 12,90)^{\prime \prime}\end{array}$ & $\begin{array}{c}10,97 \\
(10,55 ; 11,52) " \#\end{array}$ \\
\hline \multirow{2}{*}{$\begin{array}{c}\text { CAVI, од.; } \\
6,33 \\
(5,42 ; 6,85)\end{array}$} & I & $\begin{array}{c}9,87 \\
(9,12 ; 10,45)^{*}\end{array}$ & $\begin{array}{c}9,16 \\
(8,54 ; 9,93)^{\prime \prime}\end{array}$ & $\begin{array}{c}9,03 \\
(8,57 ; 9,80)^{\prime \prime}\end{array}$ & $\begin{array}{c}8,68 \\
(8,01 ; 9,16) "\end{array}$ \\
\hline & II & $\begin{array}{c}10,02 \\
(9,65 ; 10,54)^{*}\end{array}$ & $\begin{array}{c}9,13 \\
(8,24 ; 9,38) " \\
\end{array}$ & $\begin{array}{c}8,94 \\
(8,15 ; 9,05)^{\prime \prime}\end{array}$ & $\begin{array}{c}7,94 \\
(7,27 ; 8,53) " \#\end{array}$ \\
\hline \multirow{2}{*}{$\begin{array}{c}\text { ІЖА, мм рт. ст./ мл; } \\
0,64 \\
(0,61 ; 0,67)\end{array}$} & 1 & $\begin{array}{c}0,95 \\
(0,92 ; 0,97)^{*}\end{array}$ & $\begin{array}{c}0,91 \\
(0,90 ; 0,94) \\
\end{array}$ & $\begin{array}{c}0,87 \\
(0,85 ; 0,94)^{\prime \prime} \\
\end{array}$ & $\begin{array}{c}0,86 \\
(0,84 ; 0,93) " \# \\
\end{array}$ \\
\hline & II & $\begin{array}{c}0,96 \\
(0,93 ; 0,98)^{*}\end{array}$ & $\begin{array}{c}0,92 \\
(0,86 ; 0,94)\end{array}$ & $\begin{array}{c}0,87 \\
(0,84 ; 0,92) " \\
\end{array}$ & $\begin{array}{c}0,83 \\
(0,78 ; 0,92) " \#\end{array}$ \\
\hline \multirow{2}{*}{$\begin{array}{c}\text { TIMK, MM; } \\
0,80 \\
(0,76 ; 0,82)\end{array}$} & I & $\begin{array}{c}0,97 \\
(0,92 ; 1,01)^{*}\end{array}$ & $\begin{array}{c}0,97 \\
(0,90 ; 1,00)\end{array}$ & $\begin{array}{c}0,96 \\
(0,91 ; 0,98)\end{array}$ & $\begin{array}{c}0,95 \\
(0,91 ; 0,97) "\end{array}$ \\
\hline & II & $\begin{array}{c}0,97 \\
(0,90 ; 1,0)^{*}\end{array}$ & $\begin{array}{c}0,95 \\
(0,90 ; 0,98)\end{array}$ & $\begin{array}{c}0,94 \\
(0,85 ; 0,96)^{\prime \prime}\end{array}$ & $\begin{array}{c}0,92 \\
(0,85 ; 0,95) " \#\end{array}$ \\
\hline
\end{tabular}

Примітка: *-вірогідність відмінностей порівняно з показниками здорових людей (р<0,05); " - вірогідність відмінностей порівняно з показниками до лікування (р<0,05); \# - вірогідність відмінностей порівняно з показниками через 1 місяць лікування (р<0,05).

Поліпшення пружно-еластичних властивостей судин привело до позитивної динаміки ІЖА, який в процесі лікування через 6 і 12 місяців значуще зменшився, відповідно, на $8,4 \%(p<0,001)$ i $9,4 \%(p<0,001)$ та $9,5 \%(p<0,001)$ i $13,5 \%(p<0,001)$ у хворих I та II груп. При порівнянні показників через 1, 6 та 12 місяців лікування вірогідну різницю спостерігали через 1 та 12 місяців: на 5,5\% ( $p=0,0292)$ у хворих I групи та 9,8\% $(p=0,0021)$ у хворих II групи.

Спостерігали зміни ТІМК, яка достовірно зменшилася на $2,1 \%(p<0,001)$ у хворих I групи через 12 місяців лікування, що підтверджує необхідність довготривалого приймання антигіпертензивних препаратів. Канефрон Н дозволив пришвидшити цей процес - значуще зменшення TIMK на $3,1 \%(p=0,0019)$ відзначали вже через 6 місяців. Упродовж року позитивні зміни наростали та були вираженіші при застосуванні канефрону Н: TIMK зменшилася на $5,2 \%(p<0,001)$ у хворих II групи проти $2,1 \%(p<0,01)$ у хворих I групи. При порівнянні показників між собою на різних термінах дослідження вірогідну різницю спостерігали через 12 місяців лікування у хворих групи канефрону Н: на $3,2 \%(p<0,001)$ порівняно з першим місяцем.

Отже, застосування канефрону Н потенціює дію комбінованої низькодозової антигіпертензивної терапії у хворих на ХПН з АГ за рахунок позитивної динаміки показників пружно-еластичних властивостей судин, зокрема ШППХ, CAVI, IЖА та TIMK.

Дослідили динаміку показників стану ЕД. Із даних, наведених у таблиці 2, видно, як вміст ЕT-1 у крові впродовж року спостереження поступово зменшувався на $12,8 \%(p>0,05), 15,2 \%(p<0,001)$ i $24,9 \%$ ( $p<0,001)$, відповідно, через 1, 6 та 12 місяців лікування комбінованою низькодозовою антигіпертензивною терапією (табл. 2). Особливої уваги заслуговує використання канефрону Н у комплексі, оскільки достовірно знизився вміст ET-1 у крові на $14,4 \%(p=0,0353)$ вже через 1 місяць та продовжував зменшуватися на $16,2 \%$ $(p<0,001)$ та $25,5 \%(p<0,001)$ через 6 та 12 місяців лікування. При порівнянні показників через 1, 6 та 12 місяців лікування виражену різницю в змен- 
Огляди літератури, оригінальні дослідження, погляд на проблему, ювілеї

шенні вмісту ЕT-1 спостерігали тільки через 12 місяців: на $12,9 \%(p<0,001)$ та $13,9 \%(p<0,001)$ у хворих I i II груп відповідно, порівняно з першим місяцем.

При цьому спостерігали суттєве поліпшення функції ендотелію за динамічним збільшенням
ЕЗВД- на $37,0 \%(p<0,001)$ і 42,1\% ( $<<0,001)$ через 6 та 12 місяців відповідно у хворих I групи. У хворих II групи динаміка ЕЗВД виявилася швидшою, спостерігалося ії збільшення на 25,4 \% ( $<<0,001)$, $39,5 \%(p<0,001)$ та $44,6 \%(p<0,001)$ через 1, 6 та 12 місяців лікування порівняно з вихідним рівнем.

Таблиця 2. Динаміка показників ендотеліальної дисфункції судин у хворих на артеріальну гіпертензію із хронічним пієлонефритом, Ме $(25,75 \%)$

\begin{tabular}{|c|c|c|c|c|c|}
\hline \multirow{2}{*}{$\begin{array}{c}\text { Показник, од. виміру, } \\
\text { значення у здорових } \\
\text { людей }(\mathrm{n}=20)\end{array}$} & \multirow{2}{*}{$\begin{array}{l}\text { Групи } \\
\text { хворих }\end{array}$} & \multicolumn{4}{|c|}{ Період дослідження } \\
\hline & & до лікування & $\begin{array}{c}\text { через } 1 \text { міс. } \\
\text { лікування }\end{array}$ & $\begin{array}{c}\text { через } 6 \text { міс. } \\
\text { лікування }\end{array}$ & $\begin{array}{l}\text { через } 12 \text { міс. } \\
\text { лікування }\end{array}$ \\
\hline \multirow{2}{*}{$\begin{array}{c}\text { ЕT-1, пг/мл; } \\
3,21 \\
(2,06 ; 3,45)\end{array}$} & 1 & $\begin{array}{c}9,48 \\
(9,07 ; 10,01) *\end{array}$ & $\begin{array}{c}8,27 \\
(8,08 ; 9,01)\end{array}$ & $\begin{array}{c}8,04 \\
(7,87 ; 8,94)^{\prime \prime}\end{array}$ & $\begin{array}{c}7,12 \\
(7,06 ; 7,91) " \#\end{array}$ \\
\hline & II & $\begin{array}{c}9,86 \\
(9,15 ; 10,47) *\end{array}$ & $\begin{array}{c}8,44 \\
(8,02 ; 9,55) "\end{array}$ & $\begin{array}{c}8,26 \\
(8,05 ; 9,61)^{\prime \prime}\end{array}$ & $\begin{array}{c}7,35 \\
(6,98 ; 8,47) " \#\end{array}$ \\
\hline \multirow[t]{2}{*}{$\begin{array}{c}\text { ЕЗВД, \%; } \\
13,44(12,29 ; 13,55)\end{array}$} & 1 & $\begin{array}{c}5,03 \\
(4,76 ; 6,04)^{*}\end{array}$ & $\begin{array}{c}6,05 \\
(4,93 ; 6,74)\end{array}$ & $\begin{array}{c}6,89 \\
(6,43 ; 7,34)^{\prime \prime} \\
\end{array}$ & $\begin{array}{c}7,15 \\
(6,92 ; 8,01) " \#\end{array}$ \\
\hline & II & $\begin{array}{c}4,89 \\
(4,06 ; 5,52)^{*}\end{array}$ & $\begin{array}{c}6,13 \\
(5,65 ; 6,92) " \\
\end{array}$ & $\begin{array}{c}6,82 \\
(6,05 ; 7,81)^{\prime \prime} \\
\end{array}$ & $\begin{array}{c}7,07 \\
(6,75 ; 8,03) " \# \\
\end{array}$ \\
\hline \multirow{2}{*}{$\begin{array}{c}\text { ЕНВД, \%; } \\
22,64 \\
(21,95 ; 23,30)\end{array}$} & 1 & $\begin{array}{c}14,62 \\
(12,98 ; 18,81) *\end{array}$ & $\begin{array}{c}15,96 \\
(14,76 ; 16,92) "\end{array}$ & $\begin{array}{c}16,17 \\
(15,96 ; 17,11) "\end{array}$ & $\begin{array}{c}17,22 \\
(16,98 ; 18,01) " \#+\end{array}$ \\
\hline & III & $\begin{array}{c}14,23 \\
(13,28 ; 15,02) *\end{array}$ & $\begin{array}{l}15,87 \\
(14,76 ;\end{array}$ & $\begin{array}{c}16,45 \\
(16,06 ; 17,82) "\end{array}$ & $\begin{array}{c}17,08 \\
(16,35 ; 17,94) " \#+\end{array}$ \\
\hline
\end{tabular}

Примітка. * - вірогідність відмінностей порівняно з показниками здорових людей $(p<0,05)$; " - вірогідність відмінностей порівняно з показниками до лікування ( $<0,05)$; \# - вірогідність відмінностей порівняно з показниками через 1 місяць лікування $(p<0,05) ; \uparrow-$ вірогідність відмінностей порівняно з показниками через 6 місяців лікування $(p<0,05)$.

При порівнянні показників ЕЗВД через 1, 6 та 12 місяців вірогідну різницю між показниками відзначали тільки через 12 місяців: на 18,2 \% $(p=0,0133)$ та $15,3 \%(p=0,0246)$ у хворих I і II груп порівняно з першим місяцем.

Динаміка ЕНВД виявилася менш вираженою, але швидшою. У хворих I групи - через 1 місяць лікування вона збільшилася на 9,2 \% ( $p=0,0241)$, а через 6 та 12 місяців - на 10,6\% $(p=0,0188)$ та $17,8 \%$ ( $<<0,001)$, відповідно. Фактично аналогічна ситуація мала місце й у II групі - збільшення ЕНВД на $11,5 \%(p<0,001), 15,6 \%(p<0,001)$ та $20,0 \%$ $(p<0,001)$ через 1, 6 та 12 місяців лікування від вихідного значення цього показника.

При порівнянні ЕНВД через 1, 6 та 12 місяців лікування вірогідну різницю між показниками спостерігали через 12 місяців, порівняно з першим та шостим місяцем, у хворих на коморбідну патологію двох груп (всі $p<0,05)$.

Отже, призначення канефрону Н у комплексі 3 комбінованою низькодозовою антигіпертензивною терапією хворим на АГ із ХПН сприяло значущому та швидшому поліпшенню патологічно зміненої ендотеліальної функції за позитивною динамікою вмісту ЕТ-1 у крові, ЕЗВД та ЕНВД.

Слід також зазначити, що загострення захворювання нирок спостерігали в 7 (35,0 \%) пацієн- тів, які отримували комбіновану низькодозову антигіпертензивну терапію, та тільки в 1 (5,0 \%) хворого групи канефрону Н. А це значно покращує якість життя за рахунок пролонгації клініколабораторної ремісії. Побічних ефектів при застосуванні рослинного нефропротектора впродовж дослідження не виявлено. Отже, наведені дані обґрунтовують необхідність включення препарату «Канефрон Н» у лікування хворих на АГ із $\mathrm{X} \Pi \mathrm{H}$.

Таким чином, комплексне комбіноване низькодозове антигіпертензивне лікування хворих на АГ із ХПН із включенням канефрону Н позитивно впливає на перебіг та прогноз цієї коморбідності шляхом корекції субклінічних ознак ураження судин.

Висновки. 1. Канефрон Н у комплексі з комбінованою низькодозовою антигіпертензивною терапією сприяє регресу субклінічних ознак ураження судин у хворих на коморбідну патологію (артеріальну гіпертензію з хронічним пієлонефритом) за рахунок поліпшення пружно-еластичних властивостей судин (швидкості поширення пульсової хвилі, плечогомілкового судинного індексу, індексу жорсткості судин, товщини інтимо-медійного комплексу загальної сонної артерії) та зменшення ендотеліальної дисфункції (вмісту ендотеліну-1 в 
Огляди літератури, оригінальні дослідження, погляд на проблему, ювілеї крові, ендотелійзалежної та ендотелійнезалежної вазодилатації).

2. Тривале застосування препарату «Канефрон Н» у хворих на артеріальну гіпертензію із хронічним пієлонефритом доцільне, безпечне і достатньо ефективне.

Перспективи подальших досліджень. Вивчення ефективності канефрону Н в корекції системної імунозапальної активації та порушень функціонального стану нирок у хворих на артеріальну гіпертензію із хронічним пієлонефритом.

\title{
ЛІТЕРАТУРА
}

1. Longitudinal association among endothelial function, arterial stiffness and subclinical organ damage in hypertension [Електронний ресурс] / H. Tomiyama, T. Ishizu, T. Kohro [et al.] / Int. J. Cardiol. - Vol. 253. - 2018. P. 161-166.

2. Амосова К. М. Показники артеріальної жорсткості, хвиль відображення й шлуночково-артеріальної взаємодії в пацієнтів з артеріальною гіпертензією і серцевою недостатністю зі збереженою та зниженою фракцією викиду лівого шлуночка / К. М. Амосова, Н.В.Шишкіна, Ю. В. Руденко // Український кардіологічний журнал. 2017. - № 5. - С. 13-17.

3. Ефективність лікування рецидивуючого пієлонефриту з використанням Канефрону Н у хворих зі зниженою функцією нирок [Електронний ресурс] / Л. П. Мар-

тинюк, С. М. Бутвин, Т. О. Мильнікова [та ін.] // Журнал «Нирки». - 2018. - Т. 7, № 3.

4. Сміян С. І. Ефективність Канефрону Н у комплексному лікуванні субклінічної подагричної нефропатії / С. І. Сміян, М. В. Франчук // Здоров'я України. - 2015. № 3 (4). - С. 16-17.

5. Мартинюк Л. П. Ефективність застосування Канефрона Н у комплексному лікуванні хворих із діабетичною нефропатією на тлі цукрового діабету 2-го типу / Л. П. Мартинюк, Л. П. Мартинюк, О. С. Мартинюк // Семейная медицина. - № 3 (53). - 2014. - С. 69-76.

6. Чистик Т. Влияние канефрона Н на течение диабетической нефропатии у пациентов с сахарным диабетом 2-го типа/ Т. Чистик // Новини медицини та фармації. - 2015. - 2 (526).- С. 11.

\section{REFERENCES}

1. Tomiyama, H., Ishizu, T., \& Kohro, T. (2018). Longitudinal association among endothelial function, arterial stiffness and subclinical organ damage in hypertension. Int. J. Cardiol., 253, 161-166.

2. Amosova, K.M., Shyshkina, N.V., \& Rudenko, Yu.V. (2017). Pokaznyky arterialnoi zhorstkosti, khvyl vidobrazhennia i shlunochkovo-arterialnoi vzaiemodiii v patsiientiv z arterialnoiu hipertenziieiu i sertsevoiu nedostatnistiu zi zberezhenoiu ta znyzhenoiu fraktsiieiu vykydu livoho shlunochka [Indices of arterial stiffness, reflection and ventricular-arterial interaction in patients with arterial hypertension and heart failure with preserved and reduced left ventricular ejection fraction]. Ukrainskyi kardiolohichnyi zhurnal Ukrainian Cardiology Journal, 5, 13-17 [in Ukrainian].

3. Martyniuk L.P., Butvyn S.M., \& Mylnikova, T.O. (2018). Efektyvnist likuvannia retsydyvuiuchoho piielonefrytu z vykorystanniam Kanefronu N u khvorykh zi znyzhenoiu funktsiieiu nyrok [Effectiveness of treatment of recurrent pyelonephritis using Canephron $\mathrm{H}$ in patients with reduced renal function]. Zhurnal "Nyrky"- Journal "Kidneys", 7(3) [in Ukrainian].

4. Smiian, S.l., \& Franchuk, M.V. (2015). Efektyvnist Kanefronu $\mathrm{N} v$ kompleksnomu likuvanni subklinichnoi podahrychnoi nefropatii [The effectiveness of Canephron $\mathrm{H}$ in the complex treatment of subclinical gouty nephropathy]. Hazeta "Zdorovia Ukrainy" - Newspaper "Health of Ukraine", October, 16-17 [in Ukrainian].

5. Martyniuk, L.P., Martyniuk, L.P., \& Martyniuk, O.S. (2014). Efektyvnist zastosuvannia Kanefrona N u kompleksnomu likuvanni khvorykh z diabetychnoiu nefropatiieiu na tli tsukrovoho diabetu 2-ho typu [Effectiveness of Canephron $\mathrm{H}$ application in the complex treatment of patients with diabetic nephropathy on the background of type 2 diabetes mellitus]. Semeynaya meditsyna - Family Medicine, 3 (53), 69-76 [in Ukrainian].

6. Chistik, T. (2015). Vliyaniye kanefrona N na techeniye diabeticheskoy nefropatii u patsiyentov s sakharnym diabetom 2-go tipa [Effect of Canephron $\mathrm{H}$ on the course of diabetic nephropathy in patients with type 2 diabetes mellitus]. Novyny medytsyny ta farmatsii - News of Medicine and Pharmacy, 2 (526), 11 [in Russian].

\section{ЭФФЕКТИВНОСТЬ КАНЕФРОНА Н В КОМПЛЕКСНОМ ЛЕЧЕНИИ СУБКЛИНИЧЕСКИХ ПРИЗНАКОВ ПОРАЖЕНИЯ СОСУДОВ У БОЛЬНЫХ АРТЕРИАЛЬНОЙ ГИПЕРТЕНЗИЕЙ С ХРОНИЧЕСКИМ ПИЕЛОНЕФРИТОМ}

๑О. Р. Лучко

\author{
Ивано-Франковский национальный медицинский университет
}

РЕЗЮМЕ. Проанализированы результаты лечения 40 больных артериальной гипертензией (АГ) ІІ степени с хроническим пиелонефритом (ХПН), которые распределили на две группы: 20 пациентов I группы получали базовую терапию, 20 больных II группы на фоне базовой терапии получали препарат «Канефрон Н». 
Огляди літератури, оригінальні дослідження, погляд на проблему, ювілеї

Цель - изучение эффективности Канефрона Н в комплексном лечении субклинических признаков поражения сосудов у больных артериальной гипертензией с хроническим пиелонефритом.

Материал и методы. Проанализированы результаты лечения 40 больных АГ ІІ степени с ХПН, которых распределили на две группы в зависимости от лечения. I группу составили 20 больных, получавших базовую терапию: фиксированную низкодозовою комбинацию периндоприла аргинин - 2 мг, индапамида - 0,625 мг, амплодипина - 5 мг и аторвастатина - 10 мг; II - 20 больных, получавших на фоне базовой терапии канефрон Н по 2 драже 3 раза в сутки внутрь в течение месяца. Повторный курс предложенной схемы лечения проводили через 6 месяцев.

Оценку эффективности предложенного лечения определяли по динамике показателей упруго-эластичных свойств сосудов (скорость распространения пульсовой волны - СРПВ, плече-голенной сосудистый индекс - CAVI, индекс жесткости аорты - ИЖА, толщина интима-медийного комплекса - ТИМК) и эндотелиальной дисфункции (эндотелин-1 - ЕТ-1, эндотелий зависимая вазодилатация - ЭЗВД и ендотелийнезависимая вазодилатация ЭНВД).

Результаты. В ходе лечения отмечалось снижение СРПВ $(p<0,001)$ и CAVI $(p<0,001)$ у больных двух групп, однако более выраженные изменения в конце лечения были у больных II группы. В течение года ИЖА $(p<0,001)$ снижался под влиянием лечения у всех больных в одинаковой степени, но значимое уменьшение ТИМК отмечалось быстрее у больных II группы - через 6 месяцев $(p<0,01)$ по сравнению с 12 месяцами $(p<0,001)$ у больных I группы.

Канефрон Н в комплексном лечении способствовал более выраженному снижению содержания ЭТ-1 $(p<0,001)$ по сравнению с базовой терапией, при этом наблюдалось существенное улучшение функции эндотелия при более динамичным увеличением ЭЗВД ( $<<0,001)$ и ЭНВД $(p<0,001)$.

Выводы. 1. Канефрон Н в комплексе с комбинированной низкодозовой антигипертензивной терапией способствует регрессу субклинических признаков поражения сосудов у больных с коморбидной патологией.

2. Длительное применения препарата «Канефрон Н» у больных АГ с ХПН целесообразно, безопасно и достаточно эффективно.

КЛЮчЕВЫЕ СЛОВА: артериальная гипертензия; хронический пиелонефрит; субклинические признаки поражения сосудов; канефрон Н.

\section{EFFICIENCY OF CANEPHRON H IN THE COMPLEX TREATMENT OF SUBCLINICAL SIGNS OF VASCULAR DAMAGE IN PATIENTS WITH ARTERIAL HYPERTENSION AND CHRONIC PYELONEPHRITIS}

\section{Ivano-Frankivsk National Medical University}

๑O. R. Luchko

SUMMARY. The purpose of the research is to study the effectiveness of Canephron $\mathrm{H}$ in the complex treatment of subclinical signs of vascular damage in patients with arterial hypertension (HPT) with chronic pyelonephritis (CPN).

Material and Methods. The study included 40 patients with HPT and CPN, who were divided into two groups depending on the treatment. Group I consisted of 20 patients receiving baseline therapy - a fixed low-dose combination of perindopril arginine $2 \mathrm{mg}$, indapamide $0.625 \mathrm{mg}$, amlodipine $5 \mathrm{mg}$ and atorvastatin $10 \mathrm{mg}$; group II - 20 patients receiving on the background of basic therapy Canephron $\mathrm{H} 2$ tablets per os 3 times a day during a month. Repeated course of the proposed treatment scheme was performed after 6 months.

The evaluation of the effectiveness of the proposed treatment was determined by the dynamics of the parameters of the elastic properties of the vessels (velocity of the pulse wave - VPW, cardio-ankle vascular index - CAVI, aortic stiffness index - ASI, thickness intima - media complex - TIMC) and endothelial dysfunction (endothelin-1 - ET-1, endothelium dependent vasodilatation - EDVD, endothelium independent vasodilatation - EIVD).

Results. During treatment, there were decrease in VPW $(p<0.001)$ and CAVI $(p<0.001)$ in patients of two groups, however, more pronounced changes at the end of treatment were in patients of group II. During the year, ASI $(p<0.001)$ decreased from treatment in all patients equally, but a significant decrease in TIMC was noted in patients of group II - 6 months $(p<0.01)$ versus 12 months $(p<0.001)$ in patients of group I. Canephron $N$ in the complex treatment contributed to a more pronounced decrease in the content of ET-1 $(p<0.001)$ in comparison with baseline therapy, and there was a significant improvement in endothelium function with a more dynamic increase in EDVD $(p<0.001)$ and EIVD $(p<0.001)$.

Conclusions. 1. Canephron $\mathrm{H}$ in combination with combined low-dose antihypertensive therapy promotes regression of subclinical signs of vascular damage in patients with comorbid pathology. 2. The use of Canephron $\mathrm{H}$ in patients with hypertension and chronic pyelonephritis is expedient, safe and effective.

KEY WORDS: arterial hypertension; chronic pyelonephritis; subclinical signs of vascular damage; Canephron H. 